\title{
Biosimilars and the Patent Law
}

\section{MAREK ŚWIERCZYŃSKI \& ZBIGNIEW WIĘCKOWSKI}

\begin{abstract}
Biopharmaceuticals are one of the most important recent medical innovations which revolutionised many areas of medicine. Dynamic development of the market for biopharmaceuticals in recent years is related to the expiration of the IP exclusive rights on original innovative biological medicinal products. This has resulted in introduction to the market of biosimilars. One of the greatest challenges concerning the emergence of biosimilars is modifying the law to ensure balance between the market development of biosimilars and access of patients to biological therapy. The development of biopharmaceutical inventions works hand in hand with the patent system. It should be underlined that IP rights in the biopharmaceutical sector are crucial for promoting innovation due to the very long time of product development. It is exactly the area in which patents make sense to fill the gap between innovation and the risk of imitation. However, the existing patent system is too expensive and slow for biotechnology development. It should be further adapted to the needs of biopharmaceuticals.
\end{abstract}

Keywords: - Biopharmaceuticals - Biologic Medicinal Product - IP Exclusive Rights • Innovation • Intellectual Property •

CORRESPONDENCE AdDRESS: Marek Świerczyński, Cardinal Stephan Wyszynski University, Law and Administration Faculty, Warsaw, Poland, e-mail: m.swierczynski@uksw.edu.pl. Zbigniew Więckowski, Cardinal Stephan Wyszynski University, Law and Administration Faculty, Warsaw, Poland, e-mail: z.wieckowski@uksw.edu.pl. 
Introduction

Biological medicinal products (biopharmaceuticals) are medicinal products containing biological material (Mund, 2017: 4; Shih, Miller \& Harnish, 2013: 3; Geigert, 2019: 5). Their active substances are extracted from living cells and modified by appropriate biotechnological methods (Sanzo, 2017: 80; Buchholz, Collins, 2010: 380-381). Such substances have a more complex structure than traditional chemical medicinal products. Only living organisms are capable of such complexity.

Biopharmaceuticals are one of the most important recent medical innovations and triggered a revolution in many areas of medicine (Niazi, 2016: 1). They are used to treat a wide array of medical conditions such as cancer, rheumatoid, dermatological, gastrointestinal, neurological and respiratory diseases as well as metabolic disorders (Mund, 2017: 6). These products belong to the fastest growing segments of the prescription medicinal products market (Smith \& Cohen, 2017: 9-16; Cook et al. 2019: 10). Most clinical trials are now focused on biotechnology (Rajan, 2015: 223). These products also reap substantial profits for their IP rights owners (Rajan, 2015: 223). As the significance of biopharmaceuticals and their proportion among pharmaceuticals available to patients increases, it also becomes increasingly important to create a complete regulatory framework (Helled, 2017: 66). The maturation of biotechnology made such legal debate come to the forefront. Every country needs now to carefully consider and balance its own socio-economic needs, cultural and ethical norms, intellectual property laws, and international obligations in order to properly address these challenges (Helled, 2017: 67).

The dynamic development of the market for biopharmaceuticals in recent years is related to the expiration of the IP exclusive rights (including patents, Supplementary Protection Certificates (SPCs) ${ }^{1}$, data and market exclusivity) on original (patented, reference) innovative biological medicinal products (Yamauchi, 2018: 253). This has resulted in the introduction to the market of follow-on products, which we call biosimilars. Biosimilars need to be distinguished now in the legal debate, due to their legal, social, ethical and commercial importance (Rathore, Vulto, Stevenson \& Shah, 2019: 22). ${ }^{2}$ Biosimilars

\footnotetext{
1 „Supplementary protection certificates aim to offset the loss of patent protection for pharmaceutical and plant protection products that occurs due to the compulsory lengthy testing and clinical trials these products require prior to obtaining regulatory marketing approval":

https://ec.europa.eu/growth/industry/intellectual-property/patents/supplementary-protection-certificates_en (access: 03.09.2019).

${ }^{2}$ The EU is the champion of the biosimilars' uptake. According to the latest data more than 50 biosimilars of 15 innovator biologics have been approved by the EU. In contrary with the US, where only 17 biosimilar products related to nine biological medicines have been approved and only 10 are available on the market.
} 
should not be confused with generics ${ }^{3}$ (Nagel, 2018: 89; Geigert, 2019: 45-47) and another drug category called biomimics or intended copies ${ }^{4}$ (Kowalski et al. 2019: 1486; Moots, 2019: 1498).

The research and development of biopharmaceuticals is expensive and time-consuming (Mehta, 2019: 164). Furthermore, the costliness of these products make their reimbursement under national health care systems difficult (Minn, 2018: 16; Ha, Kornbluth, 2018: 276; Lu, Jacob, 2019: 36). But when IP exclusive rights to original biological medicinal product expire, generally cheaper follow-on products, that is biosimilars $^{5}$, may be introduced into the market and become subject to reimbursement by the public or private payers (Shih, Miller \& Harnish, 2013: 3). As a result, biosimilars increase patients' access to biological therapy. As a further consequence, biosimilars are then better able to compete with original products in an increasing number of therapeutic areas. They provide payers, physicians and patients with the opportunity to employ a wider range of therapeutic options (Pieńkowski, 2017: 33).

Between 2012 and 2020 we experienced a dynamic growth in the importance of biosimilars (IMS, 2014: 1) caused by the expiration of patents and other IP exclusivity rights. The scale and significance of this process is unprecedented. In this respect the socalled "patent cliff" metaphor is being used (Yu, 2017: 39-40; Calo-Fernández \& Martínez-Hurtado, 2012: 1393-1408). Examples of biologics for which patents have recently expired include human insulin, interferons and growth hormones (Pavlovic \& Prugnaud, 2012: 23-36).

One of the greatest challenges is modification in the law to ensure an appropriate balance between the market development of biosimilars and access of patients to biological therapy (Hoen, 2016: 128). ${ }^{6}$ One example of a practical question is the interchangeability

\footnotetext{
${ }^{3}$ „A generic medicine contains the same active substance(s) as the reference medicine, and it is used at the same dose(s) to treat the same disease(s). However, a generic medicine's inactive ingredients, name, appearance and packaging can be different. Generic medicines are manufactured according to the same quality standards as all other medicines. A company can only develop a generic medicine for marketing once the period of data exclusivity on the reference medicine has expired. This is usually 10 years from the date of first authorisation": https://www.ema.europa.eu/en/human-regulatory/marketing-authorisation/generic-hybrid-medicines (access 09.09.2019).

${ }^{4}$ Biological products manufactured without scrutiny, in the hope of driving cost down.

5 "It is also worth mentioning that biosimilars are not always cheaper than reference medicines. Sometimes, the manufacturers of originator biologics decrease the price of these medicines after the introduction of biosimilars onto the market, fostering the development of competition on the pharmaceutical market. Moreover, large hospitals may have the opportunity to negotiate drug prices, during tenders." (Pawłowska, Pawłowski, Krzyżaniak \& Kocić, 2019: 188).

6 "Today's pharmaceutical innovation system is firmly rooted in the patent system" (Hoen, 2016:128).
} 
(Yang, Fu \& Roskos, 2018: 545) ${ }^{7}$ (substitution or switching) of biopharmaceuticals. Unlike chemical follow-on products (generics), there is doubt whether the biosimilar can be a true clinical substitute for an original biological product in every case (Satyanarayana \& Srivastava, 2016: 218). This problem is underlined by the name itself. Biosimilar is "similar" and not "identical" to the original product (Marotto, Ceribelli \& Puttini, 2019: 16). The major clinical concern focuses on patient safety due to the potential risk of an adverse event in case of change of the product (e.g. in result of the hospital tender outcome) (McKoy \& Giles, 2019: 64). We strongly support the opinion of numerous medical societies in Europe that automatic substitution should not be permitted under the law (Satyanarayana \& Srivastava, 2016: 219; Vakil \& Fanikos, 2019; Edwards, Hercogová, Albrand \& Amiot, 2019: 3). On the other hand, interchangeability of biopharmaceuticals facilitates the marketing success of biosimilars (Burich, 2018: 70; Nagel, 2018: 95). If allowed, however, it should be based on additional scrutiny and clinical evidence to reflect confidence (Shaikh, 2016: 105).

There are fundamental questions that should be asked in the context of patent law:

1) Are we allowed to claim that biopharmaceuticals are the result of nature and should be treated as common good (part of the public domain)?

2) What would be the optimal IP framework for biosimilars? For example, should we enact new exemptions to the scope of the patent law focused on the biosimilars (e.g. similar to the Bolar exemption which aim is to exempt from patent infringement trials necessary to obtain marketing authorisation ${ }^{8}$ ).

The answers to these questions need to take into consideration recently adopted amendments to the EU regulation on Supplementary Protection Certificates (SPCs). On $1^{\text {st }}$ July 2019 Regulation (EU) 2019/933 of the European Parliament and of the Council of 20 May 2019 amending Regulation (EC) No 469/2009 concerning the supplementary protection certificate for medicinal products ${ }^{9}$ entered into force. It allows exemptions to

\footnotetext{
7 "(...) interchangeability is a health or regulatory authority designation of a biosimilar product; whereas switching is a decision made by an attending physician and substitution is an action taken by a pharmacist." (Yang, Fu \& Roskos, 2018: 545).

${ }^{8}$ The Bolar exemption in EU is governed by Directive 2004/27/EC of the European Parliament and of the Council of 31 March 2004 amending Directive 2001/83/EC on the Community code relating to medicinal products for human use. Article 10(6) provides that: "[c]onducting the necessary studies and trials with a view to the application of paragraphs 1 to 4 [i.e. bioequivalents and biosimilars] and the consequential practical requirements shall not be regarded as contrary to patent rights or to supplementary protection certificates for medicinal products." (OJ L 136, 30. 4. 2004, pp. 34-57, https://eur-lex.europa.eu/legalcontent/EN/TXT/?uri=CELEX:32004L0027- access 03/09/2019). The exact language, scope and interpretation of Bolar exemption vary across EU.

${ }^{9}$ OJ, L 153, 11. 6. 2019, pp. 1-10.
} 
extensions of patent rights through SPCs ${ }^{10}$ (Frankel, 2019: 526). The waiver would enable companies to manufacture biosimilars before the SPCs on the original biologics expire. Also, the manufacturing waiver will immediately apply to SPCs applied for on or after 1 July 2019, which means that it will be limited only to newly granted SPCs rather than existing ones. In general, this idea is based on the Bolar exemption, which is of particular importance for both generic, but also the emerging EU biosimilars industry ${ }^{11}$.

It seems obvious that the holistic approach to public health-related IP is needed (Vadi, 2016: 254). More importantly, IP rights should not be considered as absolute rights, but rather should be interpreted in the light of their goals and limits, such as ensuring access to new biological medicines (Vadi, 2016: 254). The patent system is designed to balance the interests of inventors with those of the public, including patients. Excessive protection of investors' rights has negative effects on public health (Vadi, 2016: 254). On the other hand, the existing IP system does not protect biopharmaceutical innovators in an effective way (Vadi, 2016: 254). Furthermore, existing IP laws have been blamed for some countries having limited access to biosimilars (i.e. USA) (Mehr \& Brook, 2019: 6; Chen, Yang \& Bennett, 2018: 1778; Miller, 2019: 4). There are many proposals regarding changes to the current patent system with respect to biotechnology, including, among others: 1) the creation of a patent subtype for biopharmaceuticals, 2) sui generis IP protection of genetic components of these products, 3 ) the extension of the scope of trade secret regulation with regard to biotechnology, 4) the extension of copyright protection to the DNA sequence and 5) the introduction of additional exceptions to the scope of patent (exclusivity) protection for biopharmaceuticals.

In our opinion, however, discussion on the improvements (rethinking) of the patent law in the context of biopharmaceuticals needs to be primarily aimed at fascilitating patients' access to new biological therapies (Steinberg et al., 2019). Patent law cannot be separated from the regulatory and financial considerations, such as the existing financial reimbursement model of biopharmaceuticals under national laws.

\footnotetext{
${ }^{10}$ See the amended version of article 5 Regulation (EC) No 469/2009.

${ }^{11}$ Compare well - known Polish Supreme Court' decision on Bolar exemption held of 23 October 2013 (CSK 92/13, Astellas v Polpharma). The Court decided that a third party supplier of an active pharmaceutical ingredient (API) to a generic manufacturer infringed the rights of the patent holder, because it was unable to control whether the purchaser used the API for the purposes covered by the Bolar exemption. In the following German proceeding, the Düsseldorf Court of Appeal referred questions on this same issue to the Court of Justice of the European Union (CJEU) (C-661/13). The German court has asked the CJEU to rule on whether a third party supplier can be exempted from patent infringement and under what conditions, particularly whether the third party supplier must take action to ensure the API is only used for the purpose of obtaining regulatory approval.
} 
The paper is divided into four parts. In the first, we present the main differences between chemically structured and biological drugs. The second section examines the primary attributes of biological drugs and the necessity of categorizing these type of drugs. The third section provides answers to two research questions posed in the introduction. The paper ends with a summary and conclusions.

\section{Why Biopharmaceuticals Need to be Legally Separated from Chemical Medicinal Products?}

The introduction of biopharmaceuticals turned out to be a breakthrough in the treatment of millions of patients affected by diseases for which previously used chemical medicinal products were ineffective (Helled, 2017: 48). The first biopharmaceuticals were approved in the 1980s (Buchholz \& Collins, 2010: 95-97). In the following decades, many other such medicines have been developed and marketed. Biopharmaceuticals successfully have been used to treat patients suffering from serious diseases, often previously incurable, such as cancer and chronic inflammatory conditions. Examples of biopharmaceuticals are insulins (Buchholz \& Collins, 2010: 399-400), growth hormones (Szalecki, 2017: 23-25; Buchholz \& Collins, 2010: 400-401) and monoclonal antibodies used in the treatment of autoimmune diseases or cancer (Pieńkowski, 2017: 31-33; Buchholz \& Collins, 2010: 401).

We recommend that the legal system treat biopharmaceuticals separately and distinctly from traditional medicinal products based on active chemical substances ${ }^{12}$. The existing pharmaceutical IP legal system (such as Directive 2001/83/EC of the European Parliament and of the Council of 6 November 2001 on the Community code relating to medicinal products for human use ${ }^{13}$ and complementary EU regulations) is focused on chemical products while paying inadequate attention to biopharmaceuticals, even though they have much more complex structures (Marklowska - Dzierżak, 2017: 7). As an example of these complexities, a particular series of the same biopharmaceutical product may differ from each other, and any changes in the starting biological materials and method of production affect the safety of the products (Helled, 2017: 64). This results in significant differences in their manufacturing process (Smeeding et al., 2019: 56),

\footnotetext{
${ }^{12}$ See Guide to Biological Medicines. A Focus on Biosimiliar Medicines, https://www.scribd.com/document/212444737/Guide-to-Biological-Medicines-a-Focus-on-BiosimilarMedicines (accessed 20.07.2019).

${ }^{13}$ OJ, L 311, 28. 11. 2001, pp. 67-128.
} 
marketing approval, pharmacovigilance ${ }^{14}$, and interchangeability (substitution). ${ }^{15}$

Specific differences are as follows: 1) biopharmaceuticals are characterized by greater variability (Welch, 2018: 7); 2) due to their complex structure, they present a greater risk of immunogenic reactions ${ }^{16} ; 3$ ) they are administered by injections or infusions (Morton, Stern \& Stern, 2018: 179); and 4) these products usually require dedicated transport and storage conditions, as variations in these conditions may affect their quality, effectiveness and safety (Sindelar, 2019: 244-246). That is why the traceability of specific series of biopharmaceuticals is so important.

Establishing the legal framework for biopharmaceuticals is difficult, as the long-term effects of their use is not yet fully known. Despite the studies that present a relatively high safety profile, each decision to initiate treatment with these products should be carefully considered. Therefore, the priority is to monitor their potential adverse effects (pharmacovigilance) (McKinnon et al., 2018: 47; Cohen, 2019: 32). Even in the approval procedure, each category of biopharmaceuticals needs to be given separate consideration ${ }^{17}$. The adaption of IP regulations that are inseparably connected to the approval, marketing (e.g. public tenders) and reimbursement of these products is long overdue (O'Callaghan et al., 2019: 6). In this regard, the legal system must distinguish between, and treat differently, various categories of biopharmaceuticals to take into account peculiar risks to patients associated with each.

\section{Categories of Biopharmaceuticals}

It is critically important to draw clear, legal distinctions between different categories of the biopharmaceuticals under the IP regime.

\footnotetext{
14 Comp. Guideline on good pharmacovigilance practices (GVP) Product- or Population-Specific Considerations II: Biological medicinal products, 4 August 2016, EMA/168402/2014.

${ }^{15}$ This important problem is analysed in detail in the monographs Biologiczne produkty lecznicze. Aspekty prawne (ed. M. Świerczyński), Warszawa 2016 and Leczenie biologiczne a prawa pacjenta (ed. M.

Świerczyński \& Z. Więckowski, Warszawa 2019).

${ }^{16}$ EMA, Guideline on good pharmacovigilance practices (GVP). Product-or Population-Specific Considerations II: Biological medicinal products, 4 August 2016, p. 5.

${ }^{17}$ See point 17 preamble of the Regulation (EU) No 1235/2010 of the European Parliament and of the Council of 15 December 2010 amending, as regards pharmacovigilance of medicinal products for human use, Regulation (EC) No 726/2004 laying down Community procedures for the authorisation and supervision of medicinal products for human and veterinary use and establishing a European Medicines Agency, and Regulation (EC) No 1394/2007 on advanced therapy medicinal products (OJ, L 348, 31. 12. 2010, pp. 1-16, and point 10 preamble of Directive 2010/84/EU of the European Parliament and of the Council of 15 December 2010 amending, as regards pharmacovigilance, Directive 2001/83/EC on the Community code relating to medicinal products for human use (OJ, L 348, 31. 12. 2010, pp. 74-99.
} 
The first category of biopharmaceuticals includes products based on naturally occurring substances in the environment (e.g. pig or beef insulin, pig heparin, alpha and beta interferons from human lymphocytes, erythropoietin). These active substances derive from non-genetically engineered living organisms (animals, plants, microbes) or from human blood. In such cases, patent protection must be limited and may concern only the product's manufacturing method but not the active substance itself.

The second group of substances includes those specially designed to combat the various underlying mechanisms that cause or are believed to cause disease (e.g. low molecular weight heparins, recombinant proteins, monoclonal antibodies, interleukin antagonists). Those are active substances obtained by means of cells or organisms into which foreign genes have been introduced (transgenes). These substances are biological materials modified by humans using sophisticated technical methods. In this case, not only the method of their manufacturing, but also the active substances themselves, can be the subject of patent (exclusivity) protection.

Another division of biopharmaceuticals refers to their development and marketing order. First, innovative, original products are being developed and launched on the market. Under pharmaceutical law we call them reference medicinal products. Once exclusivity expires, the biosimilars, as follow-on products, start to be marketed (Ruiz \& Calvo, 2011: 4-13). The first are approved for marketing on the basis of full regulatory documentation (dossier), while the approval of the former are based on simplified documentation (dossier), similarly to generics (chemical products). However, this simplified documentation, in contrast to the approval mechanism concerning generics (chemical products), must also include studies confirming the biological similarity of biosimilars to the reference products (Ho \& Trouvin, 2013: 2). In this case, patent law also matters because references to the regulatory documentation of original medicines are a key component of the biosimilars' documentation. The possibility of market launch of a biosimilar is closely related to both the expiration of the patent, as other exclusivity rights to the reference product as the data or market exclusivity (Pavlovic \& Prugnaud, 2003: 23-36).

Another important issue we would like to address refers to the proper terminology of biopharmaceutical follow-on products. Given the relatively new emergence of this field, unfortunately, neither EU law nor Polish law presently contain the legal definitions. For example, in the Polish language "biosimilar" name ("biopodobny" in Polish) may suggest a product of an inferior nature ("like a product"). That is why other names are proposed, such as "bio-equivalent" ("biorównoważny" in Polish). Other examples are: follow-on biologic (Mund, 2017: 5) or 'subsequent entry biologic' (Niazi, 2016: 2), 'similar 
biological medicinal product, biosubstitute, biocomparative, follow-on-protein, generic biopharmaceutical, biological near similar, subseguent Entry Biologics (SEBs), similar Biotherapeutic Products (SBP)'. As we can see, there is terminological uncertainty. We propose that these products should be universally called "biosimilar" (Nambisan, 2017: 331; Shah \& Crommelin, 2019: 265).

It is true that in a clinically relevant application, a biosimilar may gain prominence in comparison to the original reference product. The reasons for this may be that the biosimilar has a better safety profile, a higher level of effectiveness, lower immunogenicity, longer duration of action or effectiveness at a lower dose. We agree that, in general, biosimilars seem to be more innovative products than generics (Sanzo, 2017: 107). That is why some incentives for development of biosimilars, such as IP law exemptions, are needed (Sanzo, 2017: 108). However, the introduction of another exclusivity regulation for biosimilars seems to be too radical a solution (Sanzo, 2017).

Biosimilar medicinal products are most often covered by the reimbursement system, due to their lower price in comparison with reference medicinal products. It should be noted, however, that the price reduction is not as significant as in the case of generic medicinal products based on chemical substances. Typically, the price of a biosimilar medicine is 65-85 percent of the reference medicine's price (Calo-Fernández \& Martínez-Hurtado, 2012: 1393-1408; Stiff, Cline \& Feldman, 2019). The reason is higher costs of generation and registration than in the case of generic medicinal products based on chemical substances (Dolinar \& Reilly, 2013: 36-40). On the other hand, this explains why the generic industry is so eager to manufacture biosimilars, as they will ensure significantly greater profits than than do generics.

\section{$4 \quad$ Patent Law and Biosimilars}

It is obvious that the postulate of total abandonment of the IP protection for biopharmaceutical inventions is unrealistic. The mere fact that these products are forged from biological material (created by the nature) is not a sufficient reason to deny them protection under IP law. We have the same negative opinion on the proposal to exclude or limit IP protection due to its alleged collision with so-called "subjective patients right to health protection" (Delcourt, 2010: 181). 
There is no doubt that patent law plays a key role in incentivizing innovation in the biotechnology industry (Pacud, 2013: 263; Mora de, 2019). It also is worth remembering that one of the significant goals of the EU is to support innovation (Article 173 (1) of the Treaty on the Functioning of the European Union (TFEU) ${ }^{18}$ ). The patent system is one of the important instruments used to shape economic policy. Patents (and other exclusivity rights) encourage inventiveness and innovation. The need for IP tools as incentives is based on the viewpoint that in the market economy the level of innovation (production based on knowledge alone) is not optimal (Demaret, 1978: 3). It is rightly pointed out in the literature that that the innovative pharmaceutical company (and its investors) would not be willing to spend an average of $\$ 1.2$ billion, and then wait an average of 98 months for the market approval of original biopharmaceuticals, risking that the substance would then immediately be copied and sold by the biosimilars manufacturer, at significantly less expense on research and development activities (Hay, 2008: 90). In fact, it is fair to say that the biopharmaceuticals market exists thanks to patents. What's more, this happened in a situation where regulatory pharmaceutical requirements and costs incurred to ensure the safety and efficacy of medicines are constantly increasing. In this regard, patents are not a problem, but a solution to the problem, because they reward biomedical innovators for the development of intellectual property, while simultaneously allowing the market to establish the amount of the financial reward to the entrepreneurs that developed the innovation. This pro-market approach presented above seems to stand in sharp contrast to the alternative model (as we see it e.g. in the Polish reimbursement public health system) where arbitrary and capricious decisions are often made by inadequately informed officials and politicians about who should be rewarded for innovation and at what level of profit (Hay, 2008: 90).

According to some authors, the lack of knowledge (among both healthcare providers and patients (Verduzco-Aguirre et al., 2019: 88; Kurki \& Ekman, 2018: 147) about new therapies, and the delay in their implementation in the past, resulted precisely from the fact that there were no incentives in the form of patents granted to biopharmaceutical entrepreneurs.

In the light of patent law, there is no doubt that biotechnological inventions should be patentable, including both their manufacturing method and use of biological material. Both the functioning of European and national regulations for many years, as well as the long-standing practice of patenting biological material in the category of "product," means that proposals to exclude such protection are completely unrealistic.

\footnotetext{
${ }^{18}$ OJ, C 326, 26. 10. 2012, pp. 47-390.
} 
The development of biopharmaceutical inventions constituting new (breakthrough) technology moves in tandem with the patent system. In this field, high research costs and low copying costs (imitations) make patent protection particularly important (Peritz, 2011: 43). Biotechnology is an extremely expensive field, and the use of its medical applications is associated with a high degree of risk. Therefore, the search for strong legal protection by the biopharmaceutical industry is not surprising. Without proper protection for investors there would be no progress in many areas of biotechnology. In the field of biotechnology, patents have played a key role in the development of the knowledge-based industry. The transition to a knowledge-oriented economy is also closely related to the existence of the patent system (Petrusson, 2011: 94-95). It should be underlined that IP rights in the biopharmaceutical sector are crucial for promoting innovation due to the very long time of product development. It is exactly the area in which patents make sense to fill the gap between innovation and the risk of imitation. With a patent, the biopharmaceutical company can act with greater certainty that its investments are rational (Barnett, 2011: 196-197).

On the other hand, it seems too optimistic to say, as some authors do (Scott - Miller, 2010: xi), that patent law, although in existence for more than 500 years, remains fresh and alive as never before. The continuity and stability of the patent system, despite ongoing worldwide technological advances, results not only from the flexible general principles contained in it, but also from the work of lawyers and judges who should creatively read and apply patent law, reinterpreting and reinventing it for the needs of current times (Scott - Miller, 2010: xi).

The fact is that the existing patent system is extremely difficult to apply in the biotechnology industry that is dominated by products composed of both constantly changing and increasingly complex systems of many elements of genetic recombination. Drawbacks and seriously limiting features of the current patent system are that it is both too expensive and too slow-moving for biotechnology development (Holman, 2012). Its rules and methodology should and must be modified to meet the needs of biopharmaceuticals (Melethi, 2013: 111-132). The failure of the legal system to adopt will change the world by disincentivizing investors and inventors to proceed with the development of new products that could improve or even save lives.

The basic source of law in the EU is the Directive 98/44/EC of the European Parliament and of the Council of 6 July 1998 on the legal protection of biotechnological inventions ${ }^{19}$.

\footnotetext{
${ }^{19}$ OJ L 213/13, pp. 13-21.
} 
Its aims at promoting research and development in the field of genetic engineering in the European Union and harmonizes the laws of the Member States in the field of patenting biological material, distinguishing biotechnological inventions and discoveries, nonpatentable exceptions and patent protection of biotechnological inventions (Aplin \& Davis, 2017: 556-557).

There is a need for strong patent protection of biopharmaceuticals (Nambisan, 2017: 334335). Without it biopharmaceuticals innovators may not survive as independent companies (Lee \& Drexl, 2013: 1). Biopharmaceutical development from the time of invention into launch of the final product to the market is a long and always expensive process (Toritto, 2016: 56). In case of biological medicinal products, the product development period can take up to 15 years, longer than in any other industry. As a consequence of this exceedingly lengthy period of product development, a significant portion of the time protected by the patent is lost before the product even comes to market entry. The protected time used to be effectively 8 years in 1980 and now is a mere 4 years (Nambisan, 2017: 335). Much of the cost associated with medicinal product discovery and development is related to the high risk of failure in translating innovations into safe and effective products, demonstrating how challenging it is to move a molecule from discovery to commercialization (Yu, 2017: 7). The patenting process in the biopharmaceutical sector is now similar to playing a lottery as there is often uncertainty surrounding the outcome of clinical trials and the eventual economic value of patents to the proprietor (Blackstone \& Fuhr, 2018: 24-25). Therefore, cumulative patenting practices are partly inevitable because the patent holder, at least initially, cannot predict the (economic) value of all patents within the portfolio. In only one industry, namely that of medicinal products, product patents are regarded as more effective than other means of appropriation and pharmaceuticals are described as one of the few industries in which patents really do seem to matter (Minn, 2018: 17).

What then would be the optimal patent system for biosimilars? It is justified to ask whether exceptions in the field of patent protection should be extended with regard to biotechnological inventions. While there are many limitations for copyright law, the patent law provides for a rather limited set of exceptions. In most countries, they concern private use, scientific experiments and certain forms of compulsory licensing. However, there is no equivalent to fair use in the strict sense (Senftleben, 2011: 157-158). The introduction of such exemption in the case of biotechnology is recommended, among others, by Senftleben (Senftleben, 2011: 170). 


\section{$5 \quad$ Conclusions}

The critical contribution of the biopharmaceutical industry to the development of new medicines is undeniable. Over the decades, the research and development efforts of the biopharmaceutical industry has led to new treatments for a wide range of diseases, saving lives and improving the health and well-being of millions of patients (Chowdhury \& Gaigl, 2016: 5). To the benefit of individuals and society, medical innovations and technologies inevitably lead to better healthcare, improved quality of life, and increased longevity (Yu, 2017: 3).

We fully agree with the opinion that the holistic approach to public health-related IP is highly needed (Vadi, 2016: 254). The relationships between health, innovation and the law are dynamic and arguably changing faster now than ever before. The additional factors fueling this dynamic are internationalization, complexification, personalization, digitalization and fragmentation (Dutfield, 2016: 165).

The following conclusions follow from this paper:

1) biopharmaceuticals should be legally separated from traditional medicinal products based on active chemical substances;

2) clear distinctions of biopharmaceutical categories should be made under the pharmaceutical IP regime;

3) we should continue to call follow - on biopharmaceuticals as "biosimilars" ("leki biopodobne" in Polish);

4) biopharmaceuticals should not be treated as common good (part of the public domain) resulting in depravation of IP exclusivity rights. Quite the opposite, the patent law should be further adapted to the needs of biopharmaceutical industry.

5) the optimal legal regime for intellectual property rights related to biosimilars may include enactment of new exemptions to the scope of the patent protection.

\section{Note}

This article was written due to the performance of the scientific research project no. 2017/25/N/HS5/01505 titled: Legal model of biosimilars financed by National Scientific Center. 


\section{References}

Aplin, T. \& Davis, J. (2017) Intellectual Property Law (Oxford: Oxford University Press).

Barnett, J. (2011) Do patents matter? Empirical evidence on the incentive thesis, In: Litan R. (ed.) Handbook on Law, Innovation and Growth (Cheltenham: E. Elgar).

Blackstone, E. A. \& Fuhr, J. P. (2018) Innovation, Patents and Biologics: The Road to Biosimilar Competition: Factors Influencing Investment, Business Decisions and Marketing of Biosimilars, In: Gutka, H. J. (ed.) Biosimilars. Regulatory, Clinical and Biopharmaceutical Development (Springer International Publishing), pp. 23-48.

Buchholz, K. \& Collins, J. (2010) Concepts in Biotechnology. History, Science and Business (Weinheim: Wiley).

Burich, M. (2018) The Changing US Reimbursement Landscape and Biosimilars, In: Gutka, H. J. (ed.) Biosimilars. Regulatory, Clinical and Biopharmaceutical Development, (Springer International Publishing), pp. 49-73.

Calo-Fernández, B. \& Martínez-Hurtado, J. (2012) Biosimilars: company strategies to capture value from the biologics market, Pharmaceuticals, 5(12), pp. 1393-1408, doi: $10.3390 / \mathrm{ph} 5121393$.

Chen, B. K., Yang, Y. T. \& Bennett, Ch. L. (2018) Why Biologics and Biosimilar Remain So Expensive: Despite Two Wins for Biosimilars, the Supreme Court's Recent Rulings do not Solve Fundamental Barriers to Competition, Drugs, 78(17), pp. 1777-1781, doi: 10.1007/s40265-018-1009-0.

Chowdhury, A. \& Gaigl, A. (2016) The Economics of Competition Law and of Pharmaceutical Patents, In: Pitruzzella, G. \& Muscolo, G. (eds.) Competition and Patent Law in the Pharmaceutical Sector. An International Perspective, (Alphen aan den Rijn: Wolters Kluwer).

Cohen, A. D. et al. (2019) Biosimilars for Psoriasis- Experience from Europe, Current Dermatology Reports, 8(1), pp. 26-34, doi: 10.1007/s13671-019-0249-x.

Cook, J. W. et al. (2019) Academic oncology clinicians' understanding of biosimilars and information needed before prescribing, Therapeutic Advances in Medical Oncology, 11, doi: $10.1177 / 1758835918818335$.

Delcourt, D. (2010) Recherches sur l'évolution du droit international des brevets de médicaments: vers l'insertion $d u$,modèle européen" de droit pharmaceutique dans le système commercial multilatéral (PU Aix-Marseille).

Demaret, P. (1978) Patents, Territorial Restrictions, and EEC Law. A Legal and Economic Analysis, IIC Studies (New York: Verlag Chemie).

Dolinar, R. \& Reilly, M. (2013) The future of biological therapy: a pathway forward for biosimilars, Generics and Biosimilars Initiative Journal, 2(1), pp. 36-40, doi 10.5639/gabij.2013.0201.014.

Dutfield, G. (2016) Healthcare Innovation, Personalization and the Patent System, Where is the Public Interest?, In: Singh, H. \& Keswani A. Jha C. (eds.) Intellectual Property Issues in Biotechnology (Oxfordshire: MA CABI).

Edwards, Ch. J., Hercogová, J., Albrand, H. \& Amiot, A. (2019) Switching to biosimilars: current perspectives in immune-mediated inflammatory diseases, Expert Opinion on Biological Therapy, 19(10), pp. 1001-1014, doi: 10.1080/14712598.2019.1610381.

Frankel, S. (2019) The continuing excesses of trade agreements and the object and purpose of international intellectual property, International Review of Intellectual Property and Competition Law, 50(5), pp. 523-526, doi: 10.1007/s40319-019-00821-0.

Geigert, J. (2019) The Challenge of CMC Regulatory Compliance for Biopharmaceuticals (Cham: Springer Nature Switzerland AG).

Ha, Ch. Y. \& Kornbluth, A. (2018) Biosimilars in Inflammatory Bowel Disease 2017: State of the Science, State of the Art, and State of the Finances, In: Cheifetz, A. \& S. Feuerstein J. D. 
(eds.) Treatment of Inflammatory Bowel Disease with Biologics (Springer International Publishing AG), pp. 261-282, doi: 10.1007/978-3-319-60276-9_15.

Hay, J. (2008) Prices, Regulation and Innovation in Pharmaceuticals and Biotechnology, In: Farquhar, I. Summers, K. \& Sorkin, A. (eds.) The Value of Innovation: Impact on Health, Life Quality, Safety, and Regulatory Research (Bingley: Emerald Group Publishing Limited), pp. 81-99, doi: 10.1016/S0194-3960(08)16005-X.

Helled, Y. (2017) Biologics, Biosimilars and Other Idiosyncrasies, In: Mercurio, B. \& Kim, D. (eds.) Contemporary Issues in Pharmaceutical Patent Law. Setting the Framework and Exploring Policy Options (Abingdon: Routledge).

Ho, K. \& Trouvin, J. H. (2013) Biologicals' Characteristics, In: Prugnaud, J. L. \& Trouvin, J. H. (eds.) Biosimilars. A New Generation of Biologics (Paris: Springer), pp. 1-22.

Hoen, E. (2016) Private Patents and Public Health. Changing Intellectual Property Rules For Access to Medicines (Amsterdam: Health Action International = HAI).

Holman, C. M. (2012) Intellectual Property in the Age of Personal Genomics and Synthetic Biology, Biotechnology Law Report, 31(1), pp. 3-4, doi: 10.1089/blr.2012.9944.

IMS Institute for Healthcare Informatics (2014) Assessing biosimilar uptake and competition in European markets, Report, p. 1, available at: https://www.pbwt.com/content/uploads/2016/09/Assessing_biosimilar_uptake_and_comp etition_in_European_markets.pdf(16.10.2019).

Kowalski, S. C. et al. (2019) PANLAR consensus statement on biosimilars, Clinical Rheumatology, 38(5), pp. 1485-1496, doi: 10.1007/s10067-019-04496-3.

Kurki, P. \& Ekman, N. (2018) EU Perspective on Biosimilars, In: Gutka, H. J. et al. (eds.) Biosimilars (AAPS Advances in the Pharmaceutical Sciences Series book series) (Cham: Springer), pp. 145-169, doi: 10.1007/978-3-319-99680-6_7.

Lee, N. \& Drexl, J. (eds.) (2013) Pharmaceutical Innovation, Competition and Patent Law. A trilateral Perspective (Cheltenham: E. Elgar).

Lu, C. \& Jacob, E. C. (2019) Biosimilars: Not Simply Generics, US Pharmacist, 44(6), pp. 36-39.

Marklowska-Dzierżak M. (2017) Co trzeba wiedzieć o lekach biologicznych Referencyjnych i biopodobnych, In: Leki biologiczne biopodobne w praktyce klinicznej. Puls Medycyny Raport 2017, (Warszawa), pp. 7-8.

Marotto, D., Ceribelli, A. \& Puttini, P. S. (2019) Biosimilars: New guns for the treatment of rheumatologic patients? Beyond Rheumatology, 2019, 1(3), pp. 15-21.

McKinnon, R. A. et al. (2018) Biosimilarity and Interchangeability: Principles and Evidence: A systematic Review, BioDrugs, 32(1), pp. 27-52, doi: 10.1007/s40259-017-0256-z.

McKoy, J. M. \& Giles, F. J. (2019) Biosimilars: Are They Really Safe?, In: McKoy, J. M. \& West, D. P. (eds.) Cancer Policy: Pharmaceutical Safety, (Cham: Springer Nature Switzerland AG), pp. 61-73, doi: 10.1007/978-3-319-43896-2_5.

Mehr, S. R. \& Brook, R. A. (2019) Biosimilars in the USA: Will New Efforts to Spur Approvals and Access Spur Uptake and Cost Savings?, Pharmaceutical Medicine, 33(1), pp. 1-8, doi: 10.1007/s40290-018-00262-z.

Mehta, A. (2019) Downstream Processing for Biopharmaceuticals Recovery, In: Arora, D. et. al (eds.) Pharmaceuticals from Microbes, Environmental Chemistry for a Sustainable World, vol 26 (Cham: Springer Nature Switzerland AG), pp. 163-190, doi: 10.1007/978-3-03001881-8 6 .

Melethil, S. (2013) Landscape and Consideration of Intellectual Property for Development of Biosimilars, In: Wang, W. \& Singh M. (eds.) Biological Drug Products: Development and Strategies (Wiley), pp. 111-132.

Miller, H. I. (2019) Cost-Saving Biosimilars' Many Obstacles, Regulation, Summer, 42(2), pp. 24.

Minn, M. (2018) Patenting Practices in the Competitive European Pharmaceutical Market: A Thin Line between Patents, Innovation and Strategy, European Intellectual Property Review, 
40(1), pp. 16-20.

Moots, R. J. (2019) Biosimilars in the Americas: the future by consensus, Clinical Rheumatology, 38(5), pp. 1497-1499, doi: 10.1007/s10067-019-04496-3.

Mora de, F. (2019) Biosimilars: A Value Proposition, BioDrugs, 33(4), pp. 353-356, doi: 10.1007/s40259-019-00360-7.

Mund, C. (2017) Patenting biosimilars, In: Matthews, D \& Zech, H. (eds.) Research handbook on Intellectual Property and the Life Sciences (Cheltenham: E. Elgar), pp. 3-14.

Nagel, K. M. (2018) Introduction to Biologic and Biosimilar Product Development and Analysis (American Association of Pharmaceutical Scientists = AAPS Introductions in the Pharmaceutical Sciences) (Springer).

Nambisan, P. (2017) An Introduction to Ethical, Safety and Intellectual Property Rights Issues in Biotechnology (London: Academic Press).

Niazi, S.K. (2016) Biosimilars and Interchangeable Biologics. Strategic Elements, (Boca Raton: Taylor \& Francis Group).

O'Callaghan, J. et al. (2019) Regulation of biosimilar medicines and current perspectives on interchangeability and policy, European Journal of Clinical Pharmacology, 75(1), pp. 111, doi: 10.1007/s00228-018-2542-1.

Pacud, Ż. (2013) Ochrona patentowa produktów leczniczych (Warszawa: Wolters Kluwer Polska).

Pavlovic, M. \& Prugnaud, J. L. (2013) From the Biosimilar Concept to the Marketing Authorisation, In: Prugnaud, J. L. \& Trouvin, J. H. (eds.) Biosimilars. A New Generation of Biologics (Springer).

Pawłowska, I., Pawłowski, L., Krzyżaniak, N. \& Kocić, I. (2019) Perspectives of Hospital Pharmacists towards Biosimilar Medicines: A Survey of Polish Pharmacy Practice in General Hospitals, BioDrugs, 33(2), pp. 183-191, doi: 10.1007/s40259-019-00341-w.

Peritz, R. J. R. (2011) Patents and progress: The economics of patent monopoly and free access, In: Kur, A. \& Mizaras, V. (ed). The Structure of Intellectual Property Law. Can One Size Fit All? (Cheltenham: E. Elgar), doi: 10.4337/9780857931542.00010.

Petrusson, U. (2011) Patents and open access in the knowledge economy, In: Kur, A. \& Mizaras, V. (ed). The Structure of Intellectual Property Law. Can One Size Fit All? (Cheltenham: E. Elgar), doi: 10.4337/9780857931542.00012.

Pieńkowski T. (2017) Era przeciwnowotworowych leków biopodobnych dopiero nadchodzi, In: Leki biologiczne biopodobne $w$ praktyce klinicznej, Puls Medycyny Raport 2017 (Warszawa), pp. 31-33.

Rajan, K. (2015), The Experimental Machinery of Global Clinical Trials: Case Studies from India, In: Sismondo, S. \& Greene J. (ed). The Pharmaceutical Studies Reader (Wiley).

Rathore, A. S., Vulto, A. G., Stevenson, J. G. \& Shah, V. P. (2019) Challenges with Successful Commercialization of Biosimilars, BioPharm International, 32(5), pp. 22-31.

Ruiz, S. \& Calvo, G. (2011) Similar biological medicinal products: lessons learned and challenges ahead, Journal of Generic Medicines: The Business Journal for the Generic Medicines Sector, 8(1), pp. 4-13.

Sanzo, M. (2017) The Promise and Problem of Biologics, Santa Clara High Technology Law Journal, 34(1), pp. 78-109.

Satyanarayana, K. \& Srivastava, S. (2016) Promoting Access to Healthcare through Biosimilars: Addressing Intellectual Property Rights and Regulatory Barriers, In: Singh, H. B, Jha, A. \& Keswani, C. (ed). Intellectual Property Issues in Biotechnology (Oxfordshire. CABI).

Scott - Miller, J. (2010) Introduction, In: Scott- Miller, J. (eds.) Patents. Critical Concepts in Intellectual Property Law series (Cheltenham: E. Elgar).

Scott Morton, F. M., Stern, A. D. \& Stern, S. (2018) The Impact of the Entry of Biosimilars: Evidence from Europe, Review of Industrial Organization, 53(1), pp. 173-210, doi: 10.1007/s11151-018-9630-3.

Senftleben, M. (2011) Overprotection and protection overlaps in IP Law, In: Kur, A. \& Mizaras, 
V. (eds). The Structure of Intellectual Property Law. Can One Size Fit All? (Cheltenham: E. Elgar).

Shah, V. P. \& Crommelin, D. J. A. (2019) Regulatory Framework for Biosimilars, In: Crommelin, D. J. A. et. al (eds.) Pharmaceutical Biotechnology (Springer Nature Switzerland AG), pp. 265-274.

Shaikh, O. (2016) Access to Medicine versus Test Data Exclusivity. Safeguarding Flexibilities under International Law (Munich Studies on Innovation and Competition) (Munich: Springer).

Shih, H. H., Miller, P. \& Harnish, D. C. (2013) An Overview of Discovery and Development Process for Biologics, In: Wang, W. \& Singh, M. (eds). Biological Drug Products: Development and Strategies (Wiley).

Sindelar, R. D. (2019) Dispensing Biotechnology Products: Handling, Professional Education, and Product Information, In: Crommelin, D. J. A. et al. (eds.) Pharmaceutical Biotechnology, (Cham: Springer Nature Switzerland AG), pp. 239-251.

Smeeding, J. et al. (2019) Biosimilars: Considerations for Payers, Pharmacy and Therapeutics, 44(2), pp. 54-63.

Smith, W. \& Cohen A. (2017) The FDA approval process for new drugs, In: Clark, M. (ed.) Pharmaceutical and Medical Device Law. Regulation of Research, Development and Marketing, Cumulative Supplement (Arlington: Bloomberg BNA).

Steinberg J. et al. (2019) Practical Issues Concerning the Approval and Use of Biosimilar Drugs for the Treatment of Multiple Sclerosis in Latin America, Neurology and Therapy, doi: 10.1007/s40120-019-0139-y.

Stiff, K. M., Cline, A. \& Feldman, S. R. (2019) Tracking the price of existing biologics when drugs enter the market, Expert Review of Pharmacoeconomics \& Outcomes Research, 19(4), pp. 375-377, doi: 10.1080/14737167.2019.1630274.

Szalecki, M. (2017) Ludzki rekombinowany hormon wzrostu jako modelowy przykład zastosowania leku biopodobnego w endokrynologii wieku rozwojowego, In: Leki biologiczne biopodobne w praktyce klinicznej, Puls Medycyny Raport 2017 (Warszawa), pp. 23-25.

Świerczyński M. (ed.) (2016) Biologiczne produkty lecznicze. Aspekty prawne (Warszawa: Wolters Kluwer).

Toritto, B. (2016) Balancing the Human Right to Health with the Competition Law and the Intellectual Property Regime, In: Pitruzzella, G. \& Muscolo G. (eds.) Competition and Patent Law in the Pharmaceutical Sector. An International Perspective (Alphen aan den Rijn: Wolters Kluwer).

Vadi, V. (2016) Investment disputes, pharmaceutical patents and health-related goods, In: Alemanno, A. \& Bonadio, E. (eds.) The New Intellectual Property of Health. Beyond Plain Packaging (Cheltenham: E. Elgar), pp. 233-254.

Vakil, N. \& Fanikos, J. (2019) Regulatory and Clinical Perspective on Biosimilars: a Comparison of the US and European Experiences, Current Emergency and Hospital Medicine Reports, 7(3), pp. 111-117, doi: 10.1007/s40138-019-00185-2.

Verduzco-Aguirre, H. C. et al. (2019) Global Disparities: Can the World Afford Cancer?, In: Bernicker, E. H. (ed.) Cancer and Society (Cham: Springer Nature Switzerland AG), doi: 10.1007/978-3-030-05855-5_6.

Welch, A. R. (2018) Biosimilars 101: An Introduction to Biosimilars, In: Gutka, H. J. (ed.) Biosimilars. Regulatory, Clinical and Biopharmaceutical Development) (Cham: Springer International Publishing), pp. 3-21, doi: 10.1007/978-3-319-99680-6_1.

Yamauchi, P. S. (2018) Biologic and Systematic Agents in Dermatology (Cham: Springer International Publishing AG).

Yang, H., Fu, D. \& Roskos, L. (2018) Interchangeability Study Design and Analysis, In: Gutka, H. J. et al. (eds.) Biosimilars (American Association of Pharmaceutical Scientists $=$ AAPS 


$$
\begin{array}{r}
\text { MEDICINE, LAW \& SOCIETY } \\
\text { M. Świerczyński \& Z. Więckowski: Biosimilars and the Patent Law }
\end{array}
$$

Advances in the Pharmaceutical Sciences Series book series) (Cham: Springer).

Yu, H. (2017) Achieving Proof of Concept in Drug Discovery and Development (Cheltenham: E. Elgar). 